\title{
The Impact of Workforce Diversity on Organizational Effectiveness: (A Study of Selected Banks in Tigray Region of Ethiopia)
}

\author{
Dr. R. Durga Prasad \\ Assistant Professor, Department of Management, College of Business and Economics, Adigrat University, Ethiopia
}

\begin{abstract}
Diversity management is a young management discipline which originated out of many different historical and social issues. (Leopold and Harris 2009) posit that diversity management literature reveals the absence of a universally accepted definition of the term, "managing diversity". Ethiopia is the oldest independent country in Africa, commonly known as the Horn of Africa. It is at the cross-roads between Africa, the Middle East and Asia. Ethiopia is a multi-ethnic country with many indigenous languages. Ethiopians are appreciated towards warm greetings, handshakes, positive body language (smile or showing a sign of happiness) and a show of respect. The study will use different types of sampling techniques to select respondents from the purposively selected three zonal towns of the region and its capital city; such as systematic random sampling to select respondents from selected banks after proportionate sampling technique is used to determine sample size of each town. Moreover, data will be gathered through simple Random sampling method. Those selected banks under this study are both public and private banks in tigray region respectively like Commercial Bank of Ethiopia, Dashen Bank, Awash Bank, Wegagen Bank and Ambesa bank. In this study, we seek to extend the existing research on workplace diversity by conceptualizing and empirically examining the effects of different variables effectiveness on organizational and employee performance with the working environments of workgroups in exploring the impact of workplace diversity on organizational effectiveness.
\end{abstract}

Keywords: diversity, management, Ethiopia, banks, effectiveness

\section{Introduction}

Very few researches on this phenomenon have been conducted in African continent; some of them fall short of a comprehensive examination of workforce diversity. The previous studies are conceptualized workforce diversity as multi-ethnic concept. Ethiopia like many nations of the world is ethnically heterogeneous, and is characterized by other demographic diversities, which are reflective in workplaces. Business organizations in the developed and developing countries are all caught up in the globalization web, which has heralded increased demographic diversity in the workforce. This phenomenon is one of the most challenging human resource and organizational issue. Academicians and practitioners have sought to understand the impact of diversity and its management on organizational effectiveness.

Empirically, work place (workforce) diversity is found to have a contrasting dual implication on organizational effectiveness. Milliken and Martins (1996), opines that 'diversity appears to be a double-edged sword, increasing the opportunity for creativity as well as the likelihood that group members will be dissatisfied and fail to identify with the group'. Some studies have found that various forms of diversity area associated with greater innovation, improved strategic decision making, and organizational performance. Other research shows that various types of organizational diversity sometimes increase conflict, reduce social cohesion, and increase employee turnover (Jackson, Joshi, \& Erhardt, 2003; Webber \& Donahue, 2001). The demographic composition of today's workplace, occasioned by the international trend toward increased immigration and the globalization of firms is increasingly becoming diverse (Johnson, 2002; Yaprak, 2002). The demographic trends in developed and developing countries-aging workforce, growing representation of women and minorities in the workplace, and the rising number of young people in developing countries has altered homogeneous work settings of the recent past (Mor-Barak, 2005; Gorski, 2002). Thus, given these demographic and organizational trends, business organizations are contending with the challenges of effectively managing a diverse workforce.

Banking is a rapidly growing industry in Ethiopia. Currently there are 3 state owned and 16 private commercial banks; Commercial Bank of Ethiopia is the largest, controlling the majority assets of the industry. Despite strict government regulations through lending quota, bond buying, windfall tax and increased capital requirements, banks are reporting strong profit and paying high dividends. The rapid growth in the Banking sector has posed several challenges such as workforce diversity which is a natural phenomenon that has both positive and negative impacts on organizational effectiveness on how well it is managed it was more affected in the banking sector according to the recent studies, in this context this Research investigates the workforce diversity on organizational effectiveness in the selected banks in Tigray region of Ethiopia. Potential of human resources has always been considered as the heart of a business organization, an effective human resource can not only ignite the organizational excellence but it is also a cornerstone for the consistency of optimal level of business performance. Most of the banking organizations fail in this area because galvanizing diverse workforce to work as a team has been ineffective in terms of handling many dimensions, policy making, training, exposure and approach to specific and overall goals. This study therefore seeks to find out the impact of workforce diversity on organizational effectiveness using a banking sector in tigray region- 


\section{International Journal of Science and Research (IJSR) \\ ISSN (Online): 2319-7064}

Index Copernicus Value (2015): 78.96 | Impact Factor (2015): 6.391

Ethiopia. The study also finds significant correlation between some of the diversity variables it measures the organizational effectiveness. we seek to extend the existing research on workplace diversity by conceptualizing and empirically examining the effects of different variables effectiveness on organizational and employee performance with the working environments of workgroups in exploring the impact of workplace diversity on organizational effectiveness.

\section{Objectives of the project}

The project has both general and specific objective:

\section{General Objective}

The overall purpose of this study is to know the impact of workforce diversity on organizational effectiveness a study of selected banks (Public \& Private) in Tigray region.

\section{Specific Objectives}

The specific objectives of the study are:

1) To identify the workforce diversity challenges facing by the banking sector in Tigray region

2) To find out the significant relationship between diversity variables to measures the organizational effectiveness

3) To know what extent the workforce diversity destruct the employee performance and working conditions

4) To suggest suitable strategies which are effectively manage and control workforce diversity in the organizations

\section{Literature Review}

According to (Carrell, 2006), Workforce diversity refers to the ways that people differ that can affect a task or relationship within an organization such as age, gender, race, education, religion, and Culture. It is the exploration of these differences in a safe, positive, and nurturing environment. It is about understanding each other and moving beyond simple tolerance to embracing and celebrating the rich dimensions of diversity contained within each individual within the organization. Diversity management practices enhance productivity, effectiveness and sustained competitiveness. Organizations that promote and achieve a diverse workplace will attract and retain quality employees and increase customer loyalty

Greenberg (2004) also defines workplace diversity refers to the variety of differences between people in an organization including race, gender, ethnic group, age, personality, cognitive style, tenure, organizational function, education, background and more. The U.S National Partnership for Reinventing Government (NPR) Diversity Task Force in conjunction with the US Department of Commerce in their sponsored benchmark study of diversity (2007) defined diversity as including all the characteristics and experiences that define each of us as individuals. It is clear from these definitions that most scholars concur on the definition of workforce diversity. The main sources of diversity include age, race, gender, ethnicity (culture) and education although there are other sources of diversity like personal demographics; knowledge, skills, and abilities; values, beliefs, and attitudes; personality and cognitive and behavioral style; and organizational demographics.

\section{Managing Workforce Diversity}

According to Ellis and Sonnenfield (1994) argues that the challenge of meeting the needs of a culturally diverse workforce and sensitizing workers and managers to differences associated with gender, race, age and nationality in an attempt to maximize the potential productivity of all employees, has made effective management of diversity to become a prerequisite in Human Resource Management. Workforce diversity can be managed through various approaches such as affirmative action to the minority groups, diverse recruitment policies, diversity management, and strategic diversity management.

\section{Performance}

According to (Rue and Byars, 1993).Cascio (2006), performance refers to the act of performing; the carrying into execution or recognizable action, achievement or accomplishment, in the undertaking of a duty, employee performance refers to the effective discharge of one's duty for good results. It is how well an employee is fulfilling the requirements of the job defines performance as working effectiveness, that is, the way in which somebody does a job, judged by its effectiveness.

\section{Relationship between performance and workforce diversity} Fernandez (1993) argues that good workforce diversity practices in the area of human resources are believed to enhance employee and organizational performance. This is because managing diversity involves leveraging and using the cultural differences in people's skills, ideas and creativity to contribute to a common goal, and doing it in a way that gives the organization a competitive edge. Haylesand Mendez (1997) add that even recent studies have shown a strong correlation between good diversity practices and profits.

Workplace diversity is a complex, controversial, and political phenomena (Janssens\&Steyaert, 2003). It has been conceptualized by researchers from several viewpoints. Several have looked at it from a narrow perspective, while some others from a broad view (Nkomo, 1995). Scholars favorably disposed to a narrow definition argue that the concept of diversity should be restricted to specific cultural categories such as race and gender (e.g. Cross, Katz, Miller $\&$ Seashore, 1994). Some opine that diversity based on race, ethnicity and gender cannot be understood in the same way as diversity based on organizational functions, abilities or cognitive orientations (Nkomo, 1995). Moreover, the key issues of diversity are those that arise because of discrimination and exclusion of cultural groups from traditional organizations (Cross etal., 1994). Therefore, if diversity is a concept that is inclusive to all individuals, it will become very difficult to identify discrimination practices. The main concern of this standpoint is that a broad definition may imply that all differences among people are the same. Thus, diversity studies would then be reduced to the conclusion that 'everyone is different' and, if this conclusion is accepted, the concept of diversity may become "nothing more than a benign, meaningless concept" (Nkomo, 1995). The danger in narrowly defining diversity, however, is that only one dimension of cultural diversity (race, age, ethnicity, or gender) is by and large the subject of research at

\section{Volume 6 Issue 1, January 2017




\section{International Journal of Science and Research (IJSR) \\ ISSN (Online): 2319-7064}

Index Copernicus Value (2015): 78.96 | Impact Factor (2015): 6.391

a time. Since a cultural diversity dimension interacts with other dimensions of diversity, a narrow concept of diversity would be deficient by failing to recognize these interactions (Michaéla, Deanne, Paul, \&Janique, 2003).

Jackson, May \& Whitney, 1995, argues that diversity encompasses all the possible ways people can differ. Individuals, according to this school of thought, do not only differ because of their race, gender, age and other demographic categories, but also because of their values, abilities, organizational function, tenure and personality. They contend that an individual has multiple identities and that the manifold dimensions cannot be isolated in an organizational setting. Apart from bringing their race, age, ethnicity, and gender, individuals also come with their particular knowledge, personality, and cognitive style to the work place. Therefore, in order to understand the dynamics of a heterogeneous workforce, the interactive effects of multi-dimensional diversity have to be addressed. In addition, it is argued that a broadening of the concept of diversity has a potential positive effect on diversity management programs, as it will be more acceptable if it is all inclusive i.e. not only oriented towards specific demographic groups of employees

McGath, Berdahl\& Arrow (1995) conceptualized workplace diversity by developing a five cluster classification. This often cited categorization is as follows: demographic characteristics such as age, ethnicity, gender, sexual orientation, physical status, religion and education; taskrelated knowledge, skills and capacities; values, views and attitudes; personal, cognitive and attitudinal styles; Status in the organization such as one's hierarchical position, professional domain, departmental affiliation and seniority.

Michaéla, Deanne, Paul, \&Janique2003, Social categorization and similarity-attraction theory predict negative effects, such as reduction in within-group communication, decreased satisfaction and commitment, and increased labour turnover. However, from the information and decision-making perspective, positive effects of diversity are hypothesized, mainly because more diverse work-teams are expected to process information differently, as team members may bring together differing viewpoints (Williams \& O'Reilly, 1998; Cox, 1993; Pollar\& Gonzalez, 1994). This, in turn, is expected to lead to more creativity and increased performance.

Pelled,Cummings, \&Kizilos, 1999; Tsui, Egan, \& O’ Reilly, 1992have proposed that identifying individual group members with distinct groups may disrupt group dynamics. Consistent with this, research on self- categorization theory has shown that out-group members evoke more disliking, distrust, and competition than in-group members (Hogg, Cooper-Shaw, \&Holz worth, 1993). Moreover, biases against out-group members seem to unfold automatically: the perception of a salient quality (e.g., race, sex) more or less inevitably triggers a corresponding categorization (Fiske\&Neuberg, 1990).

Jackson et al., 2003, Social categorization theory, emphasize that similarities and dissimilarities can lead to categorizations which, in turn, lead to favoring one's ingroup to the detriment of one or more out-groups social (
Tajfel\& Turner, 1986). On an intra-group level, this approach is typically referred to as relational demography. Thus, categorizations within a work group (based on an attribute such as gender, race, or age) can lead to the problematic formation of sub-groups ("us" versus "them").

\section{Role of Diversity Management in Organizational Performance}

Managing Workforce Diversity effectively has a positive effect on Competitive Advantage. Competitive advantage is an element of strategy that gives an organization a distinctive competence. This competence and advantage stem from the process in which the management of diversity positively affects organizational behavior and effectiveness (Kreitner and Kinichi, 2004). Effectiveness which entails doing things right is an organizational performance factor (Unyimadu, 2006). Therefore, to effectively manage workforce diversity will help to lowers costs and improve employees' attitudes. Costs are lowered in three ways. Firstly, it reduces health care expenses. Secondly, it reduces absenteeism. Thirdly, employee recruiting and training expenses can be reduced by effectively managing workforce diversity (Kreitner and Kinichi, 2004). Effectively managed workforce diversity has a positive effect on corporate share and profits. This is because work force diversity is the minor image of consumer diversity. (Kreitner and Kinichi, 2004). Researchers such as Hofstede (cited in Schultz et al., 2003) have revealed that work force diversity promotes creativity, innovative problem solving and productivity. Kinichi, 2004). Similarly, effective education whether full or part time enhances exposure, training and development. This is what Bransford et al (2000), assert would promote understanding and congenial acceptance towards the realization of overall goals of the organization through performance.

\section{Research Methodology}

\section{Research Design}

Research design is the blueprint for fulfilling research objectives and answering research questions (John A.H. et al., 2007:20-84). It a master plans specifying the methods and procedures for collecting and analyzing the needed information. It ensures that the study would be relevant to the problem and that it uses economical procedures. The study is descriptive by nature since it describes the state of affairs as it exists at present. Then this study describes and critically assesses the impact of diversity variables on organizational effectiveness.

\section{Data Collection}

The study employed both primary and secondary sources of data collection.

\section{Primary Sources}

In order to realize the target, the study has used welldesigned structured questionnaire. The required data has been collected from the employees/ managers. The layout of the questionnaire has been kept very simple to encourage meaningful participation by the respondents. The

\section{Volume 6 Issue 1, January 2017




\section{International Journal of Science and Research (IJSR) \\ ISSN (Online): 2319-7064}

Index Copernicus Value (2015): 78.96 | Impact Factor (2015): 6.391

questionnaire contains multiple choice questions using likert scale. The questionnaire has designed to see the impact of diversity variables on organizational effectiveness, in banking sector (selected banks) at Tigray region-Ethiopia. A pilot study was conducted to validate the questionnaire and few questions were redesigned to improve the understandability of the questions. Later the questionnaires were validated by the experts.

Besides, face-to-face interviews have also been conducted with the managers/assistant managers who head the banks. The interview method of data collection is preferred due to its high response rate. Through interviews, clarification of issues have been achieved which has led to accuracy of data from the respondents.

\section{Secondary Sources}

The relevant Secondary data has been collected from files, old records, office manuals, circulars and policy papers from the banks at different towns. It helps the researchers to provide additional information where appropriate. Besides, variety of published book and government documents, websites, reports and newsletters have been reviewed to make the study fruitful.

\section{Sampling Strategy and Procedures}

The target population of the study is from selected banks of the different zones like (Adigrat from eastern zone, Shire from south western, Wukro from eastern zone and Mekelle the capital city). Since, Mekelle contains more number of branches, one branch of each selected banks will be incorporated under the study of Tigray region. The study will use different types of sampling techniques to select respondents from the purposively selected three zonal towns of the region and its capital city; such as systematic random sampling to select respondents from selected banks after proportionate sampling technique is used to determine sample size of each town. Moreover, data will be gathered through simple Random sampling method. Those selected banks under this study are both Public and Private banks in tigray region respectively like Commercial Bank of Ethiopia, Dashen Bank, Awash Bank, Wegagen Bank and Ambesa bank.

\section{Sampling Technique}

This descriptive study will be conducted in the selected banking sector (Public \& Private) of Tigray regional state. The researchers will use the sample size determination of selected banks for the study.

$$
\begin{gathered}
\mathrm{n}=\frac{\mathrm{Z}^{2}(\mathrm{P})(1-\mathrm{P})=1.645^{2} \mathrm{X}(0.5)(1-0.5)}{\mathrm{C}^{2} \quad(0.05)^{2}} \\
270.6=271(\approx)
\end{gathered}
$$

According to: "Scott Smith, Ph.D,

$\mathrm{Z}$ is your confidence level corresponds to a $\mathrm{Z}$-score. This is a constant value needed for this equation. Here are the $z$ scores for the most common confidence levels:

- $90 \%-Z$ Score $=\mathbf{1 . 6 4 5}$

- $95 \%-\mathrm{Z}$ Score $=1.96$

- $99 \%-\mathrm{Z}$ Score $=2.576$
Standard of Deviation (P) - The safe decision is to use 0.5 (maximum variability) - this is the most forgiving number and ensures that your sample will be large enough. C- With a margin of error of " $+/-5 \%$."

Proportionate sampling technique will be employed to determine sample respondents from each selected zones of the study area. Moreover, having lists of selected banks within the selected areas as a sampling frame; the selection procedure will involve a random start for the first sample respondents. Finally, in order to ensure equal chance of selection, the remaining respondents will be selected based on a systematic random sampling method. Accordingly, 271 respondents have been selected from the total.

\section{Data Processing and Analysis}

The collected data has been quantified and edited thoroughly. Later the data was coded and computed. The competed data have been tabled to the requirements. Statistical techniques will be used to analyze the data obtained from the respondents and officials. Statistical Package for the Social Sciences (SPSS) software version 20 for windows will be used in data processing. Each questionnaire will be identified by a variable name and within variables; there will be values and value labels. The coded data will then entered into SPSS. Results will be revealed in the form of frequency tables, means, and pie charts, and presented in both quantitative and qualitative terms. Calculations will be also made from these measures and compared with the existing literature to arrive at the conclusion of the study.

The given table shows that data collected from the respondents selected proportionately from the different banks at different towns are given below for the data analysis

\begin{tabular}{|c|c|c|c|c|c|}
\hline \multirow{2}{*}{ Name of the Bank } & \multicolumn{5}{|c|}{ Place of the town } \\
\cline { 2 - 6 } & Mekkele & Adigrat & Shirey & Wukro & Total \\
\hline CBE & 27 & 18 & 19 & 15 & 79 \\
\hline Dashen & 18 & 10 & 14 & 10 & 52 \\
\hline Awash & 15 & 09 & 11 & 08 & 43 \\
\hline Wegagen & 16 & 11 & 14 & 11 & 52 \\
\hline Ambessa & 14 & 10 & 12 & 09 & 45 \\
\hline & 90 & 58 & 70 & 53 & 271 \\
\hline
\end{tabular}

\section{Data Analysis \& Interpretation}

Data for this study were gleaned both from primary and secondary data sources. In addition, a random sample of work teams within the banks was undertaken, using questionnaires. The sample size surveyed is 271 from different towns. Data is gleaned from two different variables like dependent variables of employee performance measure and independent variables like-age, gender, education, tenure, religion, race level and cultural diversity.

\section{Demographic Characteristics of Respondents}




\section{International Journal of Science and Research (IJSR) \\ ISSN (Online): 2319-7064}

Index Copernicus Value (2015): 78.96 | Impact Factor (2015): 6.391

Table 1: Age of Respondents

\begin{tabular}{|c|c|c|c|}
\hline Age Group & Frequency & Percentage & $\begin{array}{c}\text { Cumulative } \\
\text { Percentage }\end{array}$ \\
\hline $20-25$ & 32 & 11.9 & 11.9 \\
\hline $26-30$ & 127 & 46.9 & 58.8 \\
\hline $31-35$ & 58 & 21.4 & 80.2 \\
\hline $36-40$ & 31 & 11.43 & 91.63 \\
\hline 41 \& Above & 23 & 8.48 & 100 \\
\hline Total & 271 & & \\
\hline
\end{tabular}

Source: Own survey 2016

Table 1 shows the age of characteristics of respondents. $46.9 \%$ are within the age group of $26-30$, while $68.3 \%$ are cumulatively within the age group of $26-35$. The data shows that a relatively high proportion of the workforce is in their active productive years.

Table 2: Gender of Respondents

\begin{tabular}{|c|c|c|c|}
\hline Gender & Frequency & Percentage & Cumulative Percentage \\
\hline Male & 224 & 82.65 & 82.65 \\
\hline Female & 47 & 17.34 & 100 \\
\hline Total & 271 & 100 & \\
\hline
\end{tabular}

\section{Source: Own survey 2016}

Table 2 shows the gender distribution of respondents. Male respondents constituted $82.65 \%$, while $17.34 \%$ were female. The data is showing that the male gender is prominent when we compare with female gender.

Table 3: Tenure of Respondents

\begin{tabular}{|c|c|c|c|}
\hline Tenure & Frequency & Percentage & Cumulative Percentage \\
\hline 1-5 Years & 142 & 52.39 & 52.39 \\
\hline 6-10 Years & 91 & 33.57 & 85.96 \\
\hline 11-15 Years & 33 & 12.17 & 98.13 \\
\hline 16-20 Years & 5 & 1.84 & 100 \\
\hline Total & 271 & 100 & \\
\hline
\end{tabular}

Source: Own survey 2016

Table 3 shows that, $52.39 \%$ of respondents have worked with the bank for a period ranging from 1-5 years, while $33.57 \%$ have been with the bank for a period ranging from 6-10 years, cumulatively $85.96 \%$ of respondents are within the range from 1-10 years. It's a good sign for the banking industry in Ethiopia; most of the people are looking towards the job opportunities in banking industry.

Table 4: Religion composition of respondents

\begin{tabular}{|c|c|c|c|}
\hline Religion & Frequency & Percentage & Cumulative Percentage \\
\hline Orthodox & 235 & 86.71 & 86.71 \\
\hline Catholic & 11 & 4.05 & 90.76 \\
\hline Protestant & 15 & 5.53 & 96.29 \\
\hline Muslim & 10 & 3.69 & 100 \\
\hline Total & 271 & 100 & \\
\hline
\end{tabular}

\section{Source: Own survey 2016}

Table 4 shows that, $86.71 \%$ of the respondents are belongs to orthodox, while $4.05 \%$ of Catholic, $5.53 \%$ of Protestant and $3.69 \%$ of Muslims. So, the religion in banking industry is up to the mark, since they are working with all different religion working together at different banks.
Table 5: Education Level of Respondents

\begin{tabular}{|c|c|c|c|}
\hline Education level & Frequency & Percentage & $\begin{array}{c}\text { Cumulative } \\
\text { Percentage }\end{array}$ \\
\hline Graduate & 208 & 76.75 & 76.75 \\
\hline $\begin{array}{c}\text { Post Graduate/ } \\
\text { Pursuing }\end{array}$ & 29 & 10.7 & 87.45 \\
\hline Others & 34 & 12.54 & 100 \\
\hline Total & 271 & 100 & \\
\hline
\end{tabular}

\section{Source: Own survey 2016}

Table 5 shows that, $76.75 \%$ of the respondents are the background of Graduation, while $10.7 \%$ of the respondents are from Post-graduation and $12.54 \%$ of the respondents are from other degree holders. Since the banking industry is highly growing industry in Ethiopia, more people are working with good background in their education levels. Cumulatively $87.45 \%$ are from both graduation and postgraduation; it resembles the importance of education in baking jobs of Ethiopia.

Table 6: Race level among Respondents

\begin{tabular}{|c|c|c|c|}
\hline Race level & Frequency & Percentage & $\begin{array}{l}\text { Cumulative } \\
\text { Percentage }\end{array}$ \\
\hline Productivity Race & 86 & 31.73 & 31.73 \\
\hline Target oriented Race & 92 & 33.94 & 65.67 \\
\hline Career development Race & 45 & 16.6 & 82.27 \\
\hline Neutral & 48 & 17.71 & 100 \\
\hline Total & 271 & 100 & \\
\hline
\end{tabular}

\section{Source: Own survey 2016}

Table 6 shows that $31.73 \%$ of the respondents are having productivity competition, while $33.94 \%$ of the respondents telling it is target oriented competition and $16.6 \%$ of the respondents are having career development competition, so finally we can say that banking industry is not only getting benefit from their employees, even they are creating better opportunities for their career and other development practices.

Table 7: Culture composition of Respondents

\begin{tabular}{|c|c|c|c|}
\hline $\begin{array}{c}\text { Workgroup Cultural } \\
\text { composition }\end{array}$ & Frequency & Percentage & $\begin{array}{c}\text { Cumulative } \\
\text { Percentage }\end{array}$ \\
\hline $\begin{array}{c}\text { People-oriented } \\
\text { culture }\end{array}$ & 96 & 35.42 & 35.42 \\
\hline $\begin{array}{c}\text { Competition-oriented } \\
\text { culture }\end{array}$ & 78 & 28.78 & 64.2 \\
\hline Growth-oriented & 59 & 21.77 & 85.97 \\
\hline Non-growth oriented & 38 & 14.02 & 100 \\
\hline Total & 271 & 100 & \\
\hline
\end{tabular}

Source: Own survey 2016

Table 7 shows that $35.42 \%$ of the respondents are responded to people-oriented culture, while $28.78 \%$ of the respondents are responded to competition-oriented culture among the employees. Cumulatively $64.2 \%$ of the respondents are having good culture among all, it's a very good sign for the banking industry since it is in growing period, and competition always helps them to get optimal productivity. 


\section{International Journal of Science and Research (IJSR) \\ ISSN (Online): 2319-7064}

Index Copernicus Value (2015): 78.96 | Impact Factor (2015): 6.391

Table 8: The above all independent variables with diversity impact

\begin{tabular}{|c|c|c|c|c|c|}
\hline Age Group & $20-25$ & $26-30$ & $31-35$ & $36-40$ & $41 \&$ Above \\
\hline Frequency & 32 & 127 & 58 & 31 & 23 \\
\hline Percentage & 11.9 & 46.9 & 21.4 & 11.43 & 8.48 \\
\hline Diversity impact & 4.6 & 18.14 & 8.28 & 4.42 & 3.28 \\
\hline Gender & Male & Female & Total & & \\
\hline Frequency & 224 & 47 & \multirow{3}{*}{271} & & \\
\hline Percentage & 82.65 & 17.34 & & & \\
\hline Diversity impact & 32 & 1.47 & & & \\
\hline Tenure & $1-5$ Years & 6-10 Years & 11-15 Years & 16-20 Years & Total \\
\hline Frequency & 142 & 91 & 33 & 5 & \multirow{3}{*}{271} \\
\hline Percentage & 52.39 & 33.57 & 12.17 & 1.84 & \\
\hline Diversity impact & 20.28 & 13 & 4.8 & 0.8 & \\
\hline Ethnicity & Orthodox & Catholic & Protestant & Muslim & Total \\
\hline Frequency & 235 & 11 & 15 & 10 & \multirow{3}{*}{271} \\
\hline Percentage & 86.71 & 4.05 & 5.53 & 3.69 & \\
\hline Diversity impact & 33.6 & 1.6 & 2.14 & 1.42 & \\
\hline Education level & Graduate & PG/Pursuing & Others & Total & \\
\hline Frequency & 208 & 29 & 34 & \multirow{3}{*}{271} & \\
\hline Percentage & 76.75 & 10.7 & 12.54 & & \\
\hline Diversity impact & 29.8 & 4.14 & \begin{tabular}{|c|}
4.8 \\
\end{tabular} & & \\
\hline Race level & Productivity Race & Target oriented Race & Career development Race & Neutral & Total \\
\hline Frequency & 86 & 92 & 45 & 48 & \multirow{3}{*}{271} \\
\hline Percentage & 31.73 & 33.94 & 16.6 & 17.71 & \\
\hline Diversity impact & 12.28 & 13.14 & 6.42 & 6.86 & \\
\hline $\begin{array}{c}\text { Workgroup Cultural } \\
\text { composition }\end{array}$ & People-oriented culture & $\begin{array}{l}\text { competition-oriented } \\
\text { culture }\end{array}$ & Growth-oriented & Non-growth oriented & \\
\hline Frequency & \begin{tabular}{|c|}
96 \\
\end{tabular} & 78 & 59 & \begin{tabular}{|c|}
38 \\
\end{tabular} & Total \\
\hline Percentage & 35.42 & 28.78 & 21.77 & 14.02 & \multirow{2}{*}{271} \\
\hline Diversity impact & 13.7 & 11.14 & 8.42 & 5.42 & \\
\hline
\end{tabular}

Source: Own survey-2016

Here, we present the correlation analysis of the heterogeneous factors investigated with the measures of group effectiveness. Table 8 shows these relationships

Table 9: Correlations of Diversity Predictors with Measures of Effectiveness

\begin{tabular}{|l|c|c|c|c|c|c|c|}
\hline & Age & Gender & Tenure & Religion & Education & Race level & Culture Composition \\
\hline Age & 1 & -0.005 & $0.777^{*}$ & 0.016 & $0.411^{*}$ & $0.235^{*}$ & $0.386^{*}$ \\
\hline Gender & -0.005 & 1 & -0.052 & -0.071 & -0.021 & -0.047 & -0.05 \\
\hline Tenure & 0.777 & -0.052 & 1 & 0.009 & $0.413^{*}$ & $0.246^{*}$ & 0.333 \\
\hline Religion & 0.016 & -0.071 & 0.009 & 1 & -0.113 & -0.081 & 0.008 \\
\hline Education & 0.411 & -0.021 & 0.413 & -0.113 & 1 & 0.299 & 0.042 \\
\hline Race level & 0.235 & -0.047 & 0.246 & -0.081 & 0.299 & 1 & 0.017 \\
\hline Culture Composition & 0.386 & -0.05 & 0.333 & 0.008 & 0.042 & 0.017 & 1 \\
\hline
\end{tabular}

*Correlation of the significant at the 0.05 level

The above table 9 indicates clearly among the variables age has high positive correlation with other variables that is when age increases the culture composition, race levels are also increased have considerable increment. Age has high positive correlation with tenure $\left(0.777^{*}\right)$ followed by education $\left(0.411^{*}\right)$ and culture composition $\left(0.386^{*}\right)$. Tenure shows good amount of positive correlation with race level $\left(0.246^{*}\right)$. This clearly indicates that tenure, age, race level and culture and education are interrelated and inter dependant by themselves.

Dependent variables like impact of workforce diversity on employee performance and working conditions
Table 10: Impact of workforce diversity on working conditions

\begin{tabular}{|c|c|c|c|}
\hline Working conditions & Frequency & Percent & $\begin{array}{c}\text { Cumulative } \\
\text { Percentage }\end{array}$ \\
\hline Mostly impact & 42 & 15.49 & 15.49 \\
\hline Moderately impact & 68 & 25.09 & 40.58 \\
\hline Least impact & 161 & 59.40 & 100 \\
\hline Total & 271 & 100 & \\
\hline
\end{tabular}

\section{Source: Own survey 2016}

Table 10 shows that $59.40 \%$ of the respondents are responded to least impact of diversity on working conditions, while $15.49 \%$ of the respondents are responded mostly impact on working conditions. Its gives clear idea that there is least diversity impact on their working conditions, so we can say that banking's are going with smooth and well-functioning of their practices.

Volume 6 Issue 1, January 2017

www.ijsr.net

Licensed Under Creative Commons Attribution CC BY 


\section{International Journal of Science and Research (IJSR) \\ ISSN (Online): 2319-7064}

Index Copernicus Value (2015): 78.96 | Impact Factor (2015): 6.391

Table 11: Impact of workforce diversity on working conditions

\begin{tabular}{|l|c|c|c|}
\hline \multicolumn{1}{|c|}{ Chi-Square Tests } & Value & Df & Asymp. Sig. (2-sided) \\
\hline Pearson Chi-Square & $10.910^{\mathrm{a}}$ & 4 & .028 \\
\hline Likelihood Ratio & 12.913 & 4 & .012 \\
\hline N of Valid Cases & 271 & & \\
\hline
\end{tabular} a. 0 cells (0.0\%) have expected count less than 5.
The minimum expected count is 8.15.

The chi-square association test results show that there is no high degree of association between workforce diversity and working conditions. The probability value 0.028 indicates that workforce diversity have not effected the working conditions (working environment) of the work force.

Table 12: Workforce diversity on Employee performance

\begin{tabular}{|c|c|c|c|}
\hline Employee Performance & Frequency & Percent & $\begin{array}{l}\text { Cumulative } \\
\text { Percentage }\end{array}$ \\
\hline Mostly influencing & 55 & 20.29 & 20.29 \\
\hline Moderately influencing & 69 & 25.46 & 45.75 \\
\hline Least influencing & 147 & 54.24 & 100 \\
\hline Total & 271 & 100 & \\
\hline
\end{tabular}

\section{Source: Own survey 2016}

Table 12 shows that $54.24 \%$ of the respondents are responded that there is least destruction, while $20.29 \%$ of the respondents are responded that mostly influencing, cumulatively $88.55 \%$ of the respondents saying that not that much influencing on employee performance, so it's very good indication to the banking industry, since it's in growing stage, that employee performance is not highly influencing with diversity.

Table 13: Workforce diversity on employee performance

\begin{tabular}{|l|c|c|c|}
\hline Chi-Square Tests & Value & df & Asymp. Sig. (2-sided) \\
\hline Pearson Chi-Square & $10.821^{\mathrm{a}}$ & 4 & .029 \\
\hline Likelihood Ratio & 11.786 & 4 & .019 \\
\hline N of Valid Cases & 271 & & \\
\hline $\begin{array}{l}\text { a. } 0 \text { cells }(0.0 \%) \text { have expected count less than } 5 . \\
\text { The minimum expected count is } 7.85 .\end{array}$ \\
\hline
\end{tabular}

The chi-square association test results show that there is no high degree of association between workforce diversity and employee performance. The probability value 0.029 indicates that workforce diversity does not destruct employee performance at work places.

\section{Summary \& Findings}

However, the study found significant correlations between some of the diversity variables, as well as individual diversity variables with the measures of organizational effectiveness. The variables age has high positive correlation with other variables that is when age increases the culture composition, race levels are also increased have considerable increment. Age has high positive correlation with tenure $\left(0.777^{*}\right)$ followed by education $\left(0.411^{*}\right)$ and culture composition $\left(0.386^{*}\right)$. Tenure shows good amount of positive correlation with race level $\left(0.246^{*}\right)$. This clearly indicates that tenure, age, race level, culture and education are interrelated and inter dependant by themselves.

There is no high degree of association between workforce diversity and working conditions. The probability value
0.028 indicates that workforce diversity has no impact on the working conditions and likewise there is no high degree of association between workforce diversity and employee performance. The probability value 0.029 indicates that workforce diversity does not destruct employee performance.

\section{Conclusion}

Overall we did not find empirical support for the two proportions about workforce diversity impact on organizational effectiveness. The result of this empirical study indicates that the impact of workforce diversity on organizational effectiveness when moderated by workforce contexts is minimal. This singular case study may not be generalized, considering some caveats. The study focused on only few dimensions which may have limited the robustness of this research. Also, the sample size used for the study may have accounted in part for the research outcome. These limitations notwithstanding, this field work has enriched the diversity literature by demonstrating empirically, that there is no casual relationship between workforce diversity and organizational effectiveness.

\section{Recommendations}

The below some of the valuable recommendations to the banks after our in-depth research, the banking sector is growing sector in Ethiopia; at this stage the top management of the organization should focus more on various diversity issues which are highly influential and value added to the organization. Identifying diversity areas and keeping away from the workplaces can increase the potentiality and effectiveness of the organizations.

- Since, banks are working competitively in the market; the management should take initiation to introduce global level practices which are more helpful to create interest and increase the cultural values among employees at work places.

- To place a competitive people in the banks, the banks should re alter the recruitment and selection practices can be conducted in the form of modernly.

- The training and development practices at banks should redesign with new technical methods it leads to create interest and eager to learn.

- The promotion and compensation practices should be more transparent to all the levels of employees, so that employees can work more hard to gain those benefits.

- Employee counseling cell should be positioned near to the work place; employees can be screened for every six months to increase their confidence levels. This screening should be conducted by some other people from outside of the banks.

- Lastly, the management should also take a part to arrange recreation and entertainment facilities at least once in a month to get relaxation from their work stress.

\section{References}

[1] Farman Afzal (2013), "Comparison of Workforce Diversity in Public and Privat Business Organizations" in Research journal Vol.3, No.2, 2013

\section{Volume 6 Issue 1, January 2017




\section{International Journal of Science and Research (IJSR) \\ ISSN (Online): 2319-7064}

Index Copernicus Value (2015): 78.96 | Impact Factor (2015): 6.391

[2] Omankhanlen Alex Ehimare, Joshua O.Ogaga-Oghene, "The Impact of workforce diversity on Organizational effectiveness", 11(3), 2011, 93-110

[3] Mercy GacheriMunjuri, "Workforce Diversity Management and Employee Performance in The Banking Sector in Kenya" 2012, Vol 3 No 1 pp. 1-21

[4] Ogbo, Ann I. KiforduAnyibuofu Anthony, "The Effect of Workforce Diversity on Organizational Performance of Selected Firms in Nigeria" Vol 5 No 10, June 2014

[5] MashaviraNhamo, Gender Diversity Management in the Banking Sector in Masvingo Urban, Zimbabwe, Volume 4, Number 1, 2013, 59-75

[6] Rajeswari. R, PSV Menon, Cultural diversity - A challenge to manage employee performance in banking sector, IJMRD 2015; 2(3): 579-581, India

[7] MerafLeykun, Banking in Ethiopia: Regulations and Procedures, Published on 07 February 2012

[8] ICCMSMS, "Building effective business relationship in Ethiopia: A cross Cultural perspective", June 26, 2014

[9] Scott Smith,

Ph.D, https://www.qualtrics.com/blog/determining-samplesize/

[10]Collins Thesaurus of the English Language (2002). Complete and Unabridged, 2nd Edition. 2002. HarperCollins Publishers. Retrieved from http://www.thefreedictionary.com/diversity.

[11]Ellis, C., Sonnenfield, J.A. (1993). Diverse Approaches to Managing Diversity. Human Resource Management Journal, Vol. 33 No.1. Emerald Publications.

[12] Greenberg, J. (2004). Workplace Diversity: Benefits, Challenges and Solutions. AlphaMeasure, Inc. Retrieved from http://www.alphameasure.com

[13] Mercy GacheriMunjuri and Rachael MuthoniMaina, DBA, Workforce Diversity Management and Employee Performance in The Banking Sector in Kenya Africa Management Review 2013, Vol 3 No 1 pp. 1-21

[14]D.PSV Menon, "Work Culture, concepts, measurement and development" distributed by PMA Management Education Foundation, May 2010

[15]Berger, C.J.; Cummings, L.L. (1979)Organizational Structure, Attitudes and Behavior,in B.M. Staw (Ed.), Research in Organizational Behavior Vol. 1, pp. 169208

[16] Jackson, S.E.; May, K.E.; Whitney, K. (1995)Dynamics of Diversity in DecisionMaking Teams, in: R.A. Guzzo\& E. Salas (Eds.), Team Effectiveness and DecisionMaking in Organizations, San Francisco, Jossey-Bass

[17] Michaéla C.S.; Deanne, N.D.H.; Paul, L.K.; Janique, A.W. (2003)Diversity and TeamOutcomes: The Moderating Effects of Outcome Interdependence and Group Longevity and the Mediating Effect of Reflexivity, Journal of Organizational Behavior, Vol. 24 (6),pp. 779-802

[18] Nkomo, S.M. (1995)Identities and the Complexity of Diversity, in: S.E. Jackson \& M.N.Ruderman (Eds.), Diversity in Work Teams. Washington DC: American Psychological Association

[19] Pelled, L. (1996)Demographic Diversity, Conflict, and Work Group Outcomes: AnIntervening Process Theory, Organization Science, Vol.7, pp. 615-631

[20]Pelled, L.H.; Eisenhardt, K.M.; Xin, K.R.
(1999)Exploring the Black Box anAnalysis

[21]Richard, O.C. (2000)Racial Diversity, Business Strategy, and Firm Performance; aResource Based View, Academy of Management Journal, Vol. 43(2), pp. $164-177$

[22] Milliken, F.J.; Martins, L.L. (1996)Searching for Common Threads: Understanding theMultiple Effects of Diversity in Organizational Groups", The Academy of ManagementReview, Vol.21 (2), pp. 102-133

[23] Richard, O.C.; Johnson, N.B. (2001)Understanding the Impact of Human ResourceDiversity |Practices on Firm Performance, Journal of Management Issues, Vol.13, pp.177-195

[24] Tilly, C. (1998). Durable Inequality. Berkeley, CA: University of California Press.

[25] Nkomo, S.M. (1995) Identities and the Complexity of Diversity, in: S.E. Jackson \& M.N.Ruderman (Eds.), Diversity in Work Teams. Washington DC: American Psychological Association

[26] Michaéla C.S.; Deanne, N.D.H.; Paul, L.K.; Janique, A.W. (2003)Diversity and TeamOutcomes: The Moderating Effects of Outcome Interdependence and Group Longevity and the Mediating Effect of Reflexivity, Journal of Organizational Behavior, Vol. 24 (6),pp. 779-802

[27] Pelled, L. (1996)Demographic Diversity, Conflict, and Work Group Outcomes: AnIntervening Process Theory, Organization Science, Vol.7, pp. 615-631

[28] Kreitner, R., and Kinichi, .A. (2004). Organizational Behaviour, Boston: McGraw-Hill.

[29] Thomas, R.R. (2006). Redefining Diversity. New York: AMACOM.

[30] Unyimadu, S.O. (2006). Business Policy and Strategy. Benin City: Harmony Publishers. 